Volume 1, Nomor 2 Oktober 2019

ISSN : 2656-9639 (Cetak)

ISSN : 2684-9046 (Online)

\title{
PANCASILA SEBAGAI IDEOLOGI PENDIDIKAN KRITIS DAN HOLISTIK DI INDONESIA
}

\author{
I Wayan Budiarta \\ Program Studi PPKn \\ Jurusan Hukum dan Kewarganegaraan \\ Fakultas Hukum dan Ilmu Sosial \\ Universitas Pendidikan Ganesha \\ Email : iwayan.budiarta0@gmail.com
}

\begin{abstract}
Abstrak
Tidak banyak yang menyadari bahwa sebuah praktik pendidikan dalam kelompok masyarakat sesungguhnya merupakan perwujudan dari orientasi ideologis yang dianut oleh masyarakat tersebut. Ideologi sebagai pandangan filosofis memberikan jawaban atas pertanyaan-pertanyaan mendasar tentang pendidikan, baik tentang hakikat dan eksistensi pendidikan hingga praktek-paktek pendidikan. Idiologi pendidikan juga dapat menjelaskan tentang bagaimana peranan pendidikan untuk melegitimasi atau melanggengkan sistem dan struktur sosial masyarakat yang ada dan berperan kritis dalam melakukan proses pembaharuan masyarakat dan transformasi budaya menuju dunia yang lebih baik dan lebih adil. Namun dari hal-hal yang ideal tadi ternyata bangsas kita masih memiliki sekelumit persoalan dalam bidang implentasi Idiologi dalam dunia pendidikan. Kegagalan sistem pendidikan kita bukan terletak pada masalah lemahnya pendidikan mencerdaskan rakyat, akan tetapi terletak pada masalah ketidakmampuan pendidikan kita dalam menyadarkan rakyat terhadap permasalahan hidup yang nyata. Tujuan dari kajian ini adalah dalam rangka mengoptimalkan fungsi pendidikan dalam proses memanusiakan manusia (humanisasi) sehingga peserta didik dan masyarakat memiliki kesadaran kritis secara personal maupun kolektif; dalam pandangan pendidikan yang membebaskan masyarakat dari dominasi ideology tertentu yang tidak sesuai dengan kepribadian bangsanya yakni dengan pembangunan pendidikan kritis di Indonesia berlandaskan nilainilai ideologi Pancasila.
\end{abstract}

Kata Kunci: Ideologi, Pedidikan Kritis, Pancasila

\begin{abstract}
Not many people realize that an educational practice in a community group is actually an embodiment of the ideological orientation adopted by the community. Ideology as a philosophical point of view provides answers to fundamental questions about education, both about the nature and existence of education to educational practices. The ideology of education can also explain the role of education to legitimize or perpetuate the existing social systems and structures of society and play a critical role in carrying out the process of community renewal and cultural transformation towards a better and fairer world. But from the ideal things, it turns out that our nation still has a few problems in the field of implementation of Idiology in the world of education. The failure of our education system lies not in the problem of weak education educating the people, but it lies in the problem of our educational inability to sensitize the people to real life problems. The purpose of this study is in order to optimize the function of education in the process of humanizing humans (humanization) so that students and the public have a critical awareness both personally and collectively; in the view of education that frees people from the dominance
\end{abstract}


Volume 1, Nomor 2 Oktober 2019

ISSN : 2656-9639 (Cetak)

ISSN : 2684-9046 (Online)

of certain ideologies that are not in accordance with the nation's personality, namely the development of critical education in Indonesia based on the values of the Pancasila ideology.

Keywords: Ideology, Critical Education, Pancasila

\section{Pendahuluan}

Praktik pendidikan di masyarakat tidaklah faqum dari pemikiranpemikiran besar masyarakatnya atau dari para pemikir-pemikir besar pendidikan dunia yang dengan generalisasigeneralisasinya memungkinkan pendidikan itu dikaji esensi-esensinya, diarahkan sasaran-sasaran dan tujuantujuannya, dimantapkan fungsi-fungsi dan peranannya di dalam masyarakat, dikembangkan kriteria-kriteria keberhasilannya, diuji validitas pemikirannya, serta dikritisi dan direfleksikan asumsi-asumsi, premispremis, proposisi-proposisi, dan konsepkonsep yang melandasinya secara koheren, sistematis, logis dan rasional (O'neil, 2001). Dari penjelasan di atas dapat pula diketahui bahwa pemikiranpemikiran filosofis pendidikan memunculkan berbagai ideologi pendidikan. Di sini pemikiran filisofis pendidikan memberikan kepada seseorang kemampuan mengkaji masalah-masalah yang muncul dari fenomena pendidikan secara keseluruhan dengan mendalam, tuntas, komprehensif, sampai tingkat eksistensi dan esensinya, antara lain berkenaan dengan konsep-konsep dan argumen pendidikan dan nilai-nilai yang bermakna yang muncul dari sasaran, tujuan, dan objektif-objektif pendidikan. Pemikiran filosofi, dengan demikian, diaplikasikan dalam dunia pendidikan dimaksudkan untuk menjelaskan konteks, proses, dan produk pendidikan sebagai suatu sistem yang utuh dan komprehensif, begitu pula dimensidimensi usaha pendidikan baik secara individual, sosial, moral, kultural, dan religius.

Membincangkan pendidikan dewasa ini, tidak dapat dilepaskan oleh beberapa pengaruh ideologi dunia yang begitu luar biasa menyebar bagaikan virus yang menggerogoti setiap sendi kehidupan social masyrakat dan bangsa, tak terkecuali di negara Indonesia sendiri. Salah satunya liberalisasi pendidikan yang menjadi sebuah sistem mutlak yang digunakan elite penguasa dalam menjalankan dan membentuk karkater pendidikan di negeri ini. Pasca reformasi, system liberalisasi pendidikan begitu luar biasa mendarah daging dalam karakter bangsa ini. Akan tetapi, pendidikan kita bukannya membaik malah makin melemah. Alih-alih memperkuat identitas dan karakter pendidikan, malah yang terjadi adalah kita seakan semakin jauh dari landasan filosofi pendidikan itu sendiri dan malah semakin menjauh dari identitas dan karakter bangsa ini. Lihat saja orientasi pembelajaran disekolah tidak lebih hanya dinilai pada keunggulan diatas selembar kertas. Padahal kita punya problem serius dan mendesak pada mentalitas dan moral bangsa, hingga yang diacu pendidikan kita seharusnya adalah nation state character building bukan pada pencapaian kecerdasan intelektual.

Ironis memang ketika melihat realitas negeri ini dalam memahami arti sebuah pendidikan, di mana sebagian elite bangsa melihat permasalahan dan menggeneralisirkannya pada satu sudut pandang saja. Menurut hemat penulis, pemahaman akan pendidikan elite bangsa terlalu positivistic yang hanya di 
ukur pada permasalahan penilaian secara normative dan menafikan pada wilayah kemanusiaan yang seharusnya di junjung tinggi sebagai sebuah proses humanisasi kemanusiaan. Proses memanusiakan manusia seakan hilang dalam sistem pendidikan yang ada pada bangsa ini. Malah yang terjadi sebaliknya, hakekat kita sebagai manusia yang bebas untuk berfikir kritis malah hilang akibat dari system pendidikan liberal tadi. Mansour Fakih (2001); mengutif kritikan Paulo Freire, bahwa, pendidikan yang selama ini dianggap sakral, penuh kebajikan ternyata mengandung juga penindasan Bagi penganut paham kritis "hakikat pendidikan pada dasarnya adalah untuk memanusiakan manusia”.

\section{Pembahasan \\ Harapan Besar Pendidiakan Indonesia}

Perubahan paradigma pendidikan di Indonesia yang berorientasi pada pendidikan berbasis masyarakat luas (broad-based education). Harapan ini menekankan perlunya materi-materi pendidikan berbagai kecakapan hidup (life skills) diberdayakan kepada generasi muda agar mereka memiliki standar kompetensi yang tinggi dan tidak tercabut dari akar kehidupan sosial budaya mereka sendiri (Suryadi, 2002 dalam Sukadi 2006). Dalam paparan di atas telah tergambar berbagai dampak dan pengaruh dari hegemoni dan penerapan paradigma CaetesianNewtonian yang bercirikan dualisme, mekanistik-deterministik, reduksionisme-atomistik,

instrumentalisme, materialismesainstisme dalam dunia pendidikan. Begitu juga berbagai persoalan dan kelemahan dunia pendidikan sebagai dampak dari penerapan paradigma tersebut, berupa pendidikan yang berdasarkan rasionalisme, empirisme, positivism, liberalisme, materialisme, dan kapitalisme. Maka sebagaimana oleh banyak pakar dan pengamat pendidikan tawarkan dipandang perlu sebuah upaya reorientasi atas paradigma pendidikan tersebut. Di antara banyak paradigma yang ditawarkan, tersebut dan sesuai dengan hakekat pendidikan yang harus mendidik anak secara paripurna, maka paradigma yang diperlukan adalah paradigma pendidikan 'holistik' yang berasal dari "Falsafah dan Idiologi Pancasila".

Lahirnya pendidikan holistik sejatinya adalah merupakan suatu respon yang bijaksana atas ekologi, budaya, dan tantangan moral pada abad ini, yang bertujuan untuk mendorong para kaum muda sebagai generasi penerus untuk dapat hidup dengan bijaksana dan bertanggung jawab dalam suatu masyarakat yang saling pengertian dan secara berkelanjutan ikut serta berperan dalam pembangunan masyarakat. Persoalan ekologi, budaya, dan tantangan moral pada abad ini itu tentu tidak bisa dipisahkan dari persoalan dan kegagalan paradigma CartesianNewtonian dalam menjawab berbagai tantangan dan perkembangan ilmu pengetahuan dan teknologi dewasa ini serta berbagai problema krusial yang diakibatkannya.

Dari sudut pandang filosofis pendidikan holistik adalah merupakan suatu filsafat pendidikan yang berangkat dari pemikiran bahwa pada dasarnya seorang individu dapat menemukan identitas, makna dan tujuan hidup melalui hubungannya dengan masyarakat, lingkungan alam, dan nilainilai spiritual. Dalam konteks ini, meminjam formulasi Heriyanto (2003) tentang paradigma 'holistik-dialogis'nya, bahwa setidaknya ada dua karateristik pendidikan holistik yang harus diperhatikan, yaitu: Pertama, paradigma pendidikan holistik berkaitan dengan pandangan antropologisnya bahwa 
'subjek' merupakan pengertian yang berkorelasi dengan 'subjek-subjek' lain. Makna 'subjek' dalam paradigma ini jauh berbeda dengan paradigma "Modern Cartesian Newtonian", yaitu tidak terisolasi, tidak tertutup, dan tidak terkungkung, melainkan berinterkoneksi dengan hal lain di alam raya. Kedua, paradigma pendidikan holistik juga berkarakter realis-pluralis, kritiskonstruktif, dan sintesis-dialogis.

Pandangan holistik tidak mengambil pola pikir dikotomis atau binary logic yang memaksa harus memilih salah satu dan membuang yang lainnya, melainkan dapat menerima realitas secara plural sebagaimana kekayaan realitas itu sendiri. Dalam pendidikan holistik sangat menapikan adanya dikotomi dalam sebagai bentunya, seperti dikotomi, dunia-akhirat, ilmu umumagama; keduanya harus ada dan diperhatikan serta dibangun dalam relasi yang tidak terputus. Pendidikan holistik membantu mengembangkan potensi individu dalam suasana pembelajaran yang lebih menyenangkan dan menggairahkan, demokratis dan humanis melalui pengalaman dalam berinteraksi dengan lingkungannya. Melalui pendidikan holistik, peserta didik diharapkan dapat menjadi dirinya sendiri. Dalam arti dapat memperoleh kebebasan psikologis, mengambil keputusan yang baik, belajar melalui cara yang sesuai dengan dirinya, memperoleh kecakapan sosial, serta dapat mengembangkan karakter dan emosionalnya (Heriyanto (2003).

\section{Pembangunan Pendidikan Kritis Dan Holistik Di Indonesia Berlandaskan Nilai-Nilai Ideologi Pancasila}

Pada era reformasi ini, masyarakat Indonesia ingin mewujudkan perubahan dalam semua aspek kehidupan terutama dalam bidang pendidikan. Tilaar (2005) menyatakan bahwa "masyarakat
Indonesia kini dalam masa transformasi, era reformasi telah lahir dan masyarakat Indonesia ingin mewujudkan perubahan dalam semua aspek kehidupannya". Di sini sektor pendidikan memiliki peran yang strategis dan fungsional dalam upaya membangun masyarakat madani di Indonesia. Pendidikan senantiasa berusaha untuk menjawab kebutuhan dan tantangan yang muncul dikalangan masyarakat sebagai konsekuensi perubahan. Melihat kondisi tersebut layak dan tepat benar jika menghadirkan ideology pendidikan kritis sebagai tandingan liberalisme pendidikan. Paradigma pendidikan kritis memaknai pendidikan sebagai upaya refleksi kritis terhadap "the dominant ideology" ke arah transformasi sosial (Paulo Fraire, 1979). Pendidikan kritis bukan pendidikan yang mengambil jarak dengan masyarakat, tetapi yang menyatu dengan masyarakat dan tidak netral, namun memihak rakyat tertindas yang termarginalkan. Visinya adalah melakukan kritik terhadap sistem dominan (terutama liberalisme) sebagai pemihakan terhadap rakyat kecil dan yang tertindas untuk menciptakan sistem sosial baru yang lebih adil. Sebagai penentang utama liberalisme, maka pendidikan kritis berupaya memanusiakan kembali manusia akibat dehumanisasi sistem liberal yang tak adil (William F. O'neill, 2001).

Selaras dengan itu, apa yang dikatakan Erich fromm (salah satu pemikir dari mazhab Frankfurt) mengatakan bahwa pendidikan perlu sekiranya mengedapankan nilai-nilai kemanusaiaan dalam proses transformasi pendidikan (Humanism Education). Proses menjadikan manusia berfikir kritis merupakan keharusan untuk mengungkap sebuah kebenaran tentang segala sesuatu yang ada di alam kosmos ini, tak terkecuali kritis terhadap segala bentuk sistem yang menafikan hakekat 
Volume 1, Nomor 2 Oktober 2019

ISSN : 2656-9639 (Cetak)

ISSN : 2684-9046 (Online)

Humansime yang jauh dari keberpihakan.

Namun, Kita sering mengotak-atik metode pembelajaran, fasilitas pembelajaran, dan kurikulumnya, tapi tidak pernah mengkaji secara serius determinan pendidikan utama, yaitu filosofi dan ideologinya. Akhirnya yang terjadi adalah mismatch antara realitas empiris, ideologi yang diambil, kebijakan yang dirumuskan serta penerapannya. Kesadaran kritis kitalah yang harusnya mampu menyingkapi realita yang terjadi pada proses pendidikan di negeri ini. Dimana, landasan filosofis pendidikan dan ideologi pendidikan harus di maknai lebih kontekstual dalam membangun tatanan moral masyarakat yang lebih baik. Di samping, itu proses kemanusiaan dalam sistem pendidikan harus menjadi sebuah kesadaran

kolektif, sehinnga hakekat pendidikan dan kemanusiaan berjalan selaras, meminjam istilah Erich Fromm "Mencintai negara tanpa mencintai kemanusiaan sama saja dengan menyembah berhala".

Pada dasarnya pendiri negara kita telah mewariskan idiologi pendidikan kritis yang gigali dari budaya kepibadian bangsa yang menurut para pounding father negara kita disebut dengan falsafah bangsa "ideologi Pancasila". Sesuatu" itu kami namakan "Pancasila", ya "Pancasila" atau Lima Sendi Negara Kami. Lima Sendi Dasar tidaklah langsung berpangkal pada Manifesto Komunis ataupun Declaration of Independence. Declaration of Independence memang, gagasangagasan dan cita-cita itu mungkin sudah ada sejak berabad-abad telah terkandung dalam bangsa kami.

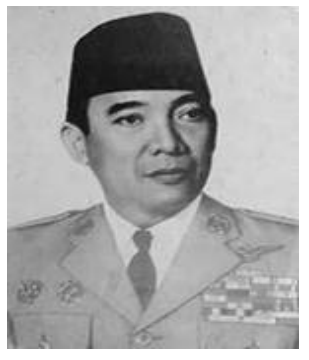

"Dan memang tidak mengherankan bahwa paham-paham mengenai kekuatan yang besar dan kejantanan itu telah timbul dalam bangsa kami selama dua ribu tahun peradaban kami dan selama berabad-abad kejayaan bangsa sebelum Imperialisme menenggelamkan kami pada suatu saat kelemahan Nasional". Ir. Soekarno Membangun Dunia Kembali To Build The World a New: Kumpulan Kata Mutiara BungKarno; 30 September 1960

Dilihat dari kajian sosio-historis, bahwa bangsa ini memiliki serangkaian nilai yang tak pernah usang oleh dinamika jaman; kapanpun-dimanapun nilai-nilai Pancasila tetaplah ada. The Founding Fathers negara kita menyebutnya sebagai rangkaian nilainilai atau sistem nilai yang terkristalisasi ke dalam nilai-nilai luhur kepribadian bangsa dengan sebutan "PANCASILA" (Kaelan, 2003; Yudi Latif, 2011). Jika kita ibaratkan hidup ini seperti sekeping mata uang logam maka: di satu sisi adalah Pancasila dan di satu sisinya lagi adalah manusia Nusantara itu sendiri. Tetapi sayangnya tidaklah semua dari kita menyadari hal ini, terkadang kita lupa bahwa kita memiliki kepribadian bangsa dan kita sering terhanyut oleh derasnya arus dan gemerlap pengaruh dari ideologi lain yang kasat mata lebih mengairahkan bagi kehidupan duniawi (rasio-empiris) kita.

\section{Implentasi Pendidikan Nasional Berdasarkan Idiologi Pancasila}

Pancasila sebagai system filsafat telah menggariskan secara jelas; menjelaskan karakteristik dari pengetahuan yang dimiliki oleh bangsa Indonesia. Pancasila yang berobjekkan manusia Indonesia secara hakiki sebagai mahluk mono-dualisme; memiliki system pengetahuan dan system nilai 
yang holistic-humanis dan religius sebagai kristalisasi nilai-nilai kepribadian bangsa. Tetapi Pancasila sebagai system nilai-nilai luhur kepribadian bangsa yang kita sebut "Filsafat Pancasila" bukanlah hanya sekedar hasil dari pemikiran atau hasil repleksi semata, atau bukanlah hanya sebuah produk belaka. Namun pada dasarnya nilai-nilai luhur kepribadian bangsa yang holistic-humanis-religius ini adalah juga untuk diimplementasikan dan direalisasikan. Dalam konteks ini, nilai luhur kepribadian bangsa ini adalah juga sebuah proses manusia pada hakikat mono-pluraslistiknya di dalam menjalankan setiap tuntutan hidupnya sebagai bagian dari masyarakat, bangsa dan negara.

Dalam kehidupan bermasyarakat, berbangsa dan bernagara Pancasila sebagai filsafat bangsa juga tidak bisa dilepaskan dalam masalah pendidikan. Secara hakiki secara yuridis formal dan visi-misi, serta tujuan pendidikan nasionalnya diarahkan dan untuk mewujudkan tujuan nasional bangsa Indonesia yang tertuang dalam Pancasila dan UUD 1945. Jika kita analisis lebih dalam, maka Pancasila sebagai falsafah bangsa (system filsafat) adalah sebagai dasar serta segaligus sebagai tujuan dari system pendidikan nasional. Maksudnya di sini adalah di dalam proses penyelenggaraan pendidikan nasional nilai-nilai filosofis dari Pancasila dijabarkan dan diimplementasikan untuk menwujudkan tujuan pendidikan nasionalnya segaligus mewujudkan tujuan Nasional bangsa Indonesia. Hal ini sangatlah memberi pengertian kepada kita, bahwa, jika pendidikan tidak ingin mencabut generasi muda dari akar budaya bangsanya yang cenderung Humanis-Holistik-Religius, maka praktik pendidikan materialistik perlu ditransformasikan ke arah yang lebih menuju kepada ideologi Pancasila (humanis-holistik-religius); tanpa harus mengabaikan nilai-nilai rasionalistik-empirik.

Sangat jelas dalam Undang-Undang Dasar 1945 (dalam pembukaan dan batang tubuh) disebutkan; dalam alinia ke-4 pembukaan UUD 1945 menyatakan; Kemudian dari pada itu untuk membentuk suatu Pemerintah Negara Indonesia yang melindungi segenap bangsa Indonesia dan seluruh tumpah darah Indonesia dan untuk memajukan kesejahteraan umum, mencerdaskan kehidupan bangsa dan ikut melaksanakan ketertiban dunia yang berdasarkan kemerdekaan, perdamaian abadi dan keadilan sosial, maka disusunlah Kemerdekaan Kebagsaan Indonesia itu dalam suatu UndangUndang Dasar Negara Indonesia, yang terbentuk dalam suatu susunan Negara Republik Indonesia, yang berkedaulatan rakyat dengan berdasar kepada: Ketuhanan Yang Maha Esa, Kemanusiaan yang adil dan beradab, Persatuan Indonesia dan Kerakyatan yang dipimpin oleh hikmat kebijaksanaan dalam permusyawaratan/perwakilan, serta dengan mewujudkan suatu Keadilan sosial bagi seluruh rakyat Indonesia.

Pasal 31 ayat 3 UUD 1945; Pemerintah mengusahakan dan menyelenggarakan satu sistem pendidikan nasional, yang meningkatkan keimanan dan ketakwaan serta akhlak mulia dalam rangka mencerdaskan kehidupan bangsa, yang diatur dengan undang-undang. Dalam aspek yuridis ini kita pahami bahwa pendidikan nasional bangsa Indonesia secara prosedural telah ditetapkan dalam dasar negara yang menegaskan kepada kita bahwa Pancasila adalah dasar negara dan falsafah bangsa di dalam penyelenggaraan pendidikan nasional. Kemudian secara lebih tegas dan 
oprasional telah tersurat dengan jelas dalam Undang-Undang Sisetem Pendidikan Nasional No. 20 tahun 2003, bahwa pendidikan nasional Indonesia adalah berdasarkan Pancasila. Pasal 2, Pendidikan nasional berdasarkan Pancasila dan Undang-Undang Dasar Negara Republik Indonesia Tahun 1945. Pasal 3, Pendidikan nasional berfungsi mengembangkan kemampuan dan membentuk watak serta peradaban bangsa yang bermartabat dalam rangka mencerdaskan kehidupan bangsa, bertujuan untuk berkembangnya potensi peserta didik agar menjadi manusia yang beriman dan bertakwa kepada Tuhan Yang Maha Esa, berakhlak mulia, sehat, berilmu, cakap, kreatif, mandiri, dan menjadi warga negara yang demokratis serta bertanggung jawab.

Yang harus dilakukan saat ini ditataran praktis adalah melakukan, karena apa, "Pendidikan Nasional Berdasarkan Pancasila" bukanlah hanya sebuah selogan semata, tetapi pendidikan nasional yang proses pewujudannya mengunakan prinsip pendidikan nasional tentang Pancasila, melalui Pancasila, dan untuk Pancasila (Education about, Trhought, and for Pancasila) dalam rangka mewujudkan tujuan pendidikan nasional bangsa Indonesia. Kemudian secara komprehensip pendidikan nasional Indonesia bersadasarkan nilai-nilai filosfis Pancasila dijalankan dengan misi sosio-pedagogis, sosio-akademi, dan sosio-kultural di dalam mewujudkan tujuan nasional pendidikannya.

Pertama, Pendidikan nasional tentang Pancasila (education about Pancasila) memberikan pemahaman kepada kita, bahwa di dalam penyelenggaraan pendidikan nasional, kita haruslah mengajarkan peserta didik untuk dapat menguasai kecakapankecakapan, pengetahuan, nilai-nilai yang ada dalam nilai-nilai filosofis Pancasila.
Kedua, Pendidikan nasional melalui Pancasila (education trhought Pancasila) maknanya adalah bahwa proses pendidikan nasional yang bersubstansikan nilai-nilai pengethuan berdasarkan Pancasila (ontologism, epistemology, aksiologi) tadi haruslah dilaksanakan dengan jalan, prosedur, cara-cara yang sejalan dengan nilai-nilai Pancasila dengan menciptakan iklim pembelajaran yang Pancasilais pula. Artinya proses pendidikan secara makro maupun mikro di sekekolah maupun di kelas menggunakan cara-cara dan prosedur yang terdapat dalam nilai-nilai filosofis Pancasila. Ketiga, Pendidikan nasional untuk Pancasila (education for Pancasila) maknanya adalah bidang kajian pendidikan nasional, penetapan tujuannya, dan proses pendidikan nasional, substansi pendidikan nasional, kesemuanya itu diarahkan utuk tujuan yang terakhir yakni untuk mewujudkan pendidikan berkarakter bangsa sesuai dengan nilai-nilai filosofis Pncasila yang "Humanis-Holistik-Religius".

Kemudian pendidikan nasional berdasarkan falsafah Pancasila yang diwujudkan degan visi sosio-pedagogis, sosio akademeis, dan sosio-kultural ini memeberikan pengertian kepada kita, bahwa proses pendidikan nasional Indonesia haruslah dilaksanakan secara holistic-humanis-dan religius jika pendidikan nasional berkaraketer bangasa ingin diwujudkan. Melalui misi sosio-pedagogis pendidikan nasional adalah mengimplementasikan nilai-nila filosofis Pancasila (humanis-holistikreligius) didalam praktik-praktik pendidikan dalam kontek mikro pendidikan (sekolah atupun di kelas) pada setiap mata pelajaran yang terimplentasikan didalam kurikulum, materi, metode, strategi, media, dan alat evaluasinya. Melalui misi sosioakademis pendidikan nasional megimplemtasikan nilai-nilai filosofis 
Pancasila diimplementasikan dalam setiap kegiatan akademis yang arah proses dan tujuannya adalah untuk mengetahui, memahami, menyikapi, dan mengimplemntasikan nilai-nilai luhur kepribadian bangsa. Kemudian misi yang terakhir adalah sosio-kultural, hal ini menggambarkan kepada kita bahwa kontek pendidikan nasional berdasarkan Pancasila adalah untuk kehidupan riil sehari-hari manusia Indonesia sebagai mahluk mono-pluralis didalam kehidupan bermasyarakat, berbangsa, dan bernegara. Jadi berdasarkan hal ini pendidikan nasional Indonesia yang secara substansi berisikan "Pengetahuan berdasarkan nilai-nilai filosofis Pncasila" sebagai refleksi manusia dalam hakikatnya sebagai mahluk monopluralis (Humanis-Holistik-religius) diimplemtasikan dalam kontek kehidupan sosial sehari-harinya dalam masyarakat, bangsa, dan negara.

Apabila pada kurikulum-kurikulum sebelumnya secara eksplisit diatur mengenai Pendidikan Pancasila yang memberi peluang diimplementasikan oleh pada siswa dalam setiap jenjang pendidikan seperti pada pada mata pelajaran PMP (kurikulum 1975); mata pelajaran PPKn (kurikulum 1994 suplemen 1999), maka pada saat ini kita akan mengimplentasikan pula nilai-nilai Pancasila dalam mata pelajaran Pendidikan Kewarganegaraan. Namun nilai-nilai Pancasila yang diajarkan dan diimplentasikan pada jenjang pendidikan tidak terlepas dari hakekat dasar Pendidikan kewarganegaraan, yang kenyataannya antara pendidikan Kewarganegaraan dengan Pancasila jika dilihat dari visi, missi dan tujuan Pendidikan Kewarganegaraan tidaklah menyimpang.

Sebagai seorang guru dapat mengembangkan domain-domain pendidikan kewarganegaraan sebagi pencerminan pengimplementasian nilai- nilai Pancasila. Dalam pengembangan domain-domain Pendidikan Kewarganegraan untuk mengimplementasikan nilai-nilai Pancasila, dipergunakan dan memanfaatkan secara selektif prinsif dan teknis perumusan tujuan pendidikan berdasarkan kerangka Taksonomi Bloom (dalam Winataputra, 2001). Sebagai alhasilnya yaitu Pendidikan Kewarganegaraan yang mewujudkan visi, misi dan tujuan Pendidikan Kewarganegaraan bermuatan nuilai-nilai Pancasila dengan tujuan akhirnya adalah warganegara yang baik (smart and good citizens) yakni warganegara yang memiliki kecerdasan (Civic Intelegence) baik intelektual, emosional, sosial, maupun spiritual; memiliki rasa bangga dan tanggung jawab (Civic Responsibility; dan mampu berpartisipasi dalam kehidupan bermasyarakat dan bernegara (Civic Participation) agar tumbuh rasa kebangsaan dan cinta tanah air, hal ini yang dinamakan sebagai warga negara Indonesia yang Pancasilais.

\section{Kesimpulan}

Perubahan paradigma pendidikan di Indonesia yang berorientasi pada pendidikan berbasis masyarakat luas (broad-based education). Harapan ini menekankan perlunya materi-materi pendidikan berbagai kecakapan hidup (life skills) diberdayakan kepada generasi muda agar mereka memiliki standar kompetensi yang tinggi dan tidak tercabut dari akar kehidupan sosial budaya mereka sendiri. Mengoptimalkan fungsi pendidikan dalam proses memanusiakan manusia (humanisasi) sehingga peserta didik dan masyarakat memiliki kesadaran kritis secara personal maupun kolektif; pendidikan yang membebaskan masyarakat dari dominasi ideology tertentu yang tidak sesuai dengan 
kepribadian bangsanya yakni dengan PEMBANGUNAN PENDIDIKAN KRITIS DI INDONESIA BERLANDASKAN NILAI-NILAI IDEOLOGI PANCASILA. IMPLENTASI "Pendidikan Nasional Berdasarkan Pancasila" bukanlah hanya sebuah selogan semata, tetapi pendidikan nasional yang proses pewujudannya mengunakan prinsip pendidikan nasional tentang Pancasila, melalui Pancasila, dan untuk Pancasila (Education about, Trhought, and for Pancasila) dalam rangka mewujudkan tujuan pendidikan nasional bangsa Indonesia. Kemudian secara komprehensip pendidikan nasional Indonesia bersadasarkan nilai-nilai filosfis Pancasila dijalankan dengan misi sosio-pedagogis, sosio-akademi, dan sosio-kultural di dalam mewujudkan tujuan nasional pendidikannya.

\section{Daftar Pustaka}

CCE. (2004). Kami Bangsa Indonesia. California: Centre for Civic Education.

Fritjof Capra. 1997. The Turning Poin (Titik Balik Peradaban; Sains, Masyarakat, Dan Kebangkitan Kebudayaan). Yogyakarta: Jejak

H.A.R Tilaar. 2005. Manifesto Pendidikan Nasional, Tinjauan Dari Perspektif ostmodernisme dan Studi Kultural. Jakarta: PT Kompas Media Nusantara

Giroux. H. A. (1981). Ideology, Culture, and the Process of Schooling. Philadelphia: Temple University Press.

Kaelan, H. (2003). Pendidikan Pancasila. Yogyakarta; Paradigma.

Pai, Young. 1990. Cultural Foundations of Education. New York: Macmillan Publishing Company.

Sukadi. 2006. Pendidikan IPS Sebagai Rekonstruksi Pengalaman Budaya
Berbasis Ideologi Tri Hitha Karana (Studi Etnografi tentang Pengaruh Masyarakat terhadap Program Pendidikan IPS pada SMU Negeri 1 Ubud-Bali). Desertasi. Bandug: Universitas Pendidikan Indonesia.

Sukadi. dkk 2010. Rekonstruksi Pemikiran Belajar dan Pembelajaran PKN SD Sebagai Yadnya dalam Rangka Perwujudan Dharma Agama dan Dharma Negara Berbasis Konstruktivisme. Laporan Penelitian Hibah Bersaing Tahap II. Singaraja: Universitas Pendidikan Ganesha.

William F. O'neil .2002. IdiologiIdiologi Pendidikan; Pengantar oleh Mansour Fakih. Yogyakarta: Pustaka Pelajar

Widja, I G. 2009. Pendidikan Sebagai Ideologi Budaya; Suatu Pengantar ke Arah Pendidikan Kritis. Program Magister dan Doktor Kajian Budaya. Unoversitas Udayana

Yudi Latif. 2011. Negara Paripurna Historisitas, Rasionalitas, dan Aktualitas Pancasila. Jakarta: Gramedia Pustaka Utama. Undang-Undang Dasar Negara Republik Indonesia Tahun 1945.

....... Undang-Undang Republik Indonesia Nomor 20 Tahun 2003 tentang Sistem Pendidikan Nasional. 